\title{
Aklimatisasi dan Evaluasi Produksi Mutan Rumput Gajah Kultivar Taiwan
}

\author{
Acclimatization and Evaluation of Elephant Grass cv Taiwan Production \\ B Gea', P D M H Karti', I Prihantoro', A Husni² $^{2}$
}

Corresponding email:

berlin634@gmail.com

1) Departemen Ilmu Nutrisi dan Teknologi Pakan, Fakultas Peternakan, Institut Pertanian Bogor (Bogor Agricultural University/IPB University)

${ }^{2)}$ Balai Besar Penelitian dan Pengembangan Bioteknologi dan Sumberdaya Genetik Pertanian

\section{ABSTRACT}

Cultivation of the Elephant Grass cv Taiwan with tissue culture requires an acclimatization stage, therefore this study aims to find the best planting media and the effect of plant age and evaluation of production elephant grass cv taiwan mutant and nutrient content. Acclimatization was carried out in a greenhouse using sand, soil, and a combination of $50 \%$ sand with $50 \%$ soil, and the mutant type T2, T4 and K4. The acclimation process uses the Factorial RAL method with factor A type of mutant and factor B type of planting media and the parameters assessed are leaf length, number of leaves and plant mortality rate. Production evaluation uses the RAL method and the parameters observed to see elephant grass production are plant height, stem diameter, leaf width, number of tillers and amount of plant biomass production. Proximate analysis is used to show the nutritional value of plants that have been selected individually using scoring assessments. The results of the acclimatization study showed that the planting media that had the lowest mortality rate were sand and soil combination media (22\%) followed by soil planting media (27\%) and the planting media that had the highest mortality rate was sand media (30\%). The results of the production evaluation stage showed that the highest average harvest weight was found in T4 mutants with an average weight of 1353 g clump $^{-1}$ harvest ${ }^{-1}$, followed by T2 mutants which had an average of 1198 g clump $^{-1}$ harvest $^{-1}$ and the lowest harvest weight was found in $\mathrm{K} 4$ mutants with an average of $1002 \mathrm{~g} \mathrm{clump}^{-1}$ harvest $^{-1}$. Based on the research results obtained the best planting media for the acclimation process of elephant grass cv Taiwan mutants is a combination of sand and soil media (1:1). The results of the evaluation stage of T4 mutant production are the best mutants based on morphological performance and production of plant biomass. Proximate analysis of selected plants shows that plants with mutant T2PT7 species have the best nutritional value, with nutritional content of PK 11.71 and SK 24.67.

Key words: acclimatization, Elephant grass cv Taiwan, proximate analysis

\section{ABSTRAK}

Budidaya rumput gajah Taiwan dengan kultur jaringan memerlukan tahap aklimatisasi, oleh karena itu penelitian ini bertujuan untuk menemukan media tanam terbaik dan pengaruh umur tanaman serta evaluasi produksi rumput gajah Taiwan mutan dan kandungan nutrisi. Aklimatisasi dilakukan di rumah kaca menggunakan pasir, tanah, dan kombinasi 50\% pasir dengan 50\% tanah, dan tipe mutan T2, T4 dan K4. Proses aklimatisasi menggunakan metode RAL Faktorial dengan faktor A jenis mutan dan faktor B jenis media tanam dan parameter yang dinilai adalah panjang daun, jumlah daun dan tingkat kematian tanaman. Evaluasi produksi menggunakan metode RAL dan parameter yang diamati untuk melihat produksi rumput gajah adalah tinggi tanaman, diameter batang, lebar daun, jumlah anakan dan jumlah produksi biomassa tanaman. Analisis proksimat digunakan untuk menunjukkan nilai nutrisi tanaman yang telah dipilih secara individual menggunakan penilaian skoring. Hasil penelitian aklimatisasi menunjukkan bahwa media tanam yang memiliki angka kematian terendah adalah media kombinasi pasir dan tanah (22\%) diikuti oleh media tanam tanah $(27 \%)$ dan media tanam yang memiliki angka kematian tertinggi adalah media pasir (30\%). Hasil penelitian tahap evaluasi produksi menunjukkan rataan berat panen tertinggi terdapat pada mutan $\mathrm{T} 4$ dengan berat rata-rata 1353 g rumpun $^{-1}$ panen $^{-1}$, diikuti mutan T2 yang memiliki rataan $1198 \mathrm{~g}_{\text {rumpun }}^{-1}$ panen $^{-1}$ dan berat panen terendah terdapat pada mutan K4 dengan rataan 1002 g rumpun $^{-1}$ panen $^{-1}$. Berdasarkan hasil penelitian didapatkan media tanam terbaik untuk proses aklimatisasi mutan rumput gajah kultivar Taiwan adalah media kombinasi pasir dan tanah (1:1). Hasil tahap evaluasi produksi mutan T4 merupakan mutan terbaik berdasarkan performa morfologis dan produksi biomassa tanaman. Analisis proksimat dari tanaman terpilih menunjukkan bahwa tanaman yang jenis mutan T2PT7 memiliki nilai gizi terbaik, dengan kandungan nutrisi PK 11.71 dan SK 24.67. 


\section{PENDAHULUAN}

Hijauan pakan merupakan sumber bahan pakan terbesar yang harus ada dalam setiap pemberian pakan ruminansia. Permasalahan utama yang selalu dihadapi peternak ruminansia yang memiliki lahan terbatas adalah ketersediaan hijauan pakan. Indonesia merupakan daerah tropis sehingga intensitas matahari yang panjang akan mempengaruhi kuantitas dan kualitas hijauan pakan (Heuze et al., 2016). Rumput gajah merupakan salah satu hijauan pakan yang disukai ternak dan dapat tumbuh baik didaerah tropis. Adaptasi rumput gajah yang baik membuat rumput ini dapat ditanam didataran rendah dan didataran tinggi dengan pertumbuhannya yang relatif cepat sehingga sangat layak untuk dikembangkan dan menjadi salah satu sumber utama bahan hijauan pakan (Chemisquy et al. 2010).

Sampai saat ini Rumput Gajah Taiwan merupakan jenis rumput yang banyak ditanam karena memiliki ukuran daun yang cukup besar dan batang yang panjang, yaitu dapat mencapai $4-5 \mathrm{~m}$, batangnya lunak, daun lebar berbulu lembut, tingkat nutrisi cukup baik, dan pada batang muda pangkal batang bawah dekat tanah berwarna kemerah-merahan (Sajimin et al. 2001). Namun demikian rumput ini tidak tahan hidup di daerah hujan yang terus menerus dan didaerah kering. Tanah tempat rumput ini ditanam harus subur, gembur, tidak bercadas, dan $\mathrm{pH}$ tanahnya 5-7. Untuk itu diperlukan generasi baru rumput gajah yang dapat hidup di kedua kondisi tersebut.

Rumput gajah Taiwan dapat diberikan dalam bentuk segar, atau dapat juga diolah menjadi silase dan hay apabila kondisinya berlimpah pada saat musim penghujan sebagai cadangan bahan makanan pada musim kemarau (Elly et al. 2008). Rumput gajah Taiwan memiliki kandungan nutrisi protein kasar 10,85\%, serat kasar 30-32\% dan Ca 0,24\%-0,31\% (Manurung et al. 2001). Hasil penelitian Nurahyu et al. (2009) tentang introduksi beberapa jenis rumput dan leguminosa unggul sebagai hijauan pakan menunjukkan produksi hijauan segar dan keringnya tertinggi yaitu pada rumput gajah varietas Taiwan sehingga cultivar ini digunakan sebagai bahan genetik induksi mutasi dalam penelitian ini untuk memperoleh generasi baru rumput gajah tersebut.

Aklimatisasi merupakan adaptasi planlet dari lingkungan terkendali (in vitro) ke lingkungan in vivo sebelum ditanam dilapang (Husni et al.2004). Populasi tunas/planlet mutan yang diperoleh dari hasil induksi mutasi secara in vitro rumput gajah Taiwan perlu diaklimatisasi agar bisa dilanjutkan evaluasi lebih lanjut dirumah kaca dan lapangan. Selanjutnya ditanam dilapang untuk memperoleh produktivitas dan kandungan nutrisinya. Keberhasilan untuk meningkatkan produktivitas dan keunggulan suatu tanaman salah satunya diawali dengan penggunaan benih/bibit unggul bermutu. (Husni \& Kosmiatin 2018).

Dengan diperolehnya rumput gajah generasi baru tersebut produktivitas dan mutu rumput gajah dapat ditingkatkan. Penelitian ini merupakan penelitian lanjutan dari penelitian kultur tanaman rumput gajah Taiwan yang menggunakan perlakuan iradiasi sinar gamma. Penelitian ini bertujuan untuk mendapatkan media tanam terbaik dalam proses aklimatisasi mutan rumput gajah Taiwan yang telah melalui proses induksi mutasi, dan untuk mengevaluasi produksi dan kualitas nutrien.

\section{METODE}

\section{Materi}

Alat yang digunakan meliputi peralatan untuk pembuatan media tanam yang terdiri dari polybag ukuran 8x9 cm, wadah transparan bekas kemasan air mineral, cangkul, sendok semen, timbangan, cutter, dan spray.

Bahan yang digunakan dalam penelitian ini meliputi tanaman mutan rumput gajah (T2, T4 dan K4), media tanam berupa pasir, tanah, pupuk kandang dan fungisida Dithane M-45.

\section{Prosedur Penelitian}

Penelitian ini terdiri dari 3 tahap yakni aklimatisasi, evaluasi produksi dan kualitas nutrien dari mutan rumput gajah kultivar Taiwan.

\section{Aklimatisasi Mutan Rumput Gajah Kultivar Taiwan Skala Rumah Kaca}

Kandidat planlet untuk diaklimatisasi memiliki organ planlet lengkap (akar, batang, daun), warna pucuk batang hijau dan tidak tembus pandang, pertumbuhannya kekar, akar memenuhi media, ukuran tinggi tanaman $3-4 \mathrm{~cm}$.

Tahapan aklimatisasi meliputi:

1. Menyiapkan wadah

Wadah merupakan tempat yang berisi media tumbuh tanaman hasil kultur. Jenis wadah yang digunakan yaitu pot terbuat dari polybag berukuran $8 \times 9 \mathrm{~cm}$.

2. Menyiapkan media

Media yang digunakan berupa tanah, pasir, kombinasi tanah dan pasir dengan perbandingan 1:1 dan setiap media ditambahkan pupuk kandang dengan perbandingan $1: 3$

3. Penanaman mutan

Mutan dikeluarkan dari botol kultur, dibersihkan menggunakan larutan fungisida Dithane-M45. Daun mutan dipangkas ukuran 3-4 cm, kemudian ditanam ke media yang sudah dipersiapkan lalu disusun sesuai pola letak penanaman.

Tahapan pemeliharaan tanaman meliputi:

1. Tanaman disiram setiap pagi dan sore hari selama 44 hari.

2. Tanaman dibersihkan dari gulma dan parasit setiap 3 hari.

3. Daun tanaman yang layu dibuang setiap hari.

4. Tanaman yang mati langsung dipindahkan untuk mencegah kontaminasi dengan tanaman yang lain. 


\section{Evaluasi Produksi Mutan Rumput Gajah Kultivar Taiwan Skala Lapang}

Tanaman yang hidup pada tahap aklimatisasi selanjutnya dipindahkan ke lahan lapang. Tahapan penanaman mutan evaluasi produksi meliputi:

Persiapan Lahan

1. Lahan dibersihkan dari lalang dan rumput lainnya.

2. Dibuat lubang tanam dengan jarak tanam $50 \times 100 \mathrm{~cm}$ sebanyak 68 lubang.

3. Kemudian lahan disiram dengan air dan ditahap ini tidak ada penggunaan pupuk.

Penanaman Mutan

1. Tanaman dipisahkan dari plastik polybag.

2. Tanaman dimasukan kedalam lubang tanam yang sudah dipersiapkan.

3. Tanam dilahan dibiarkan tumbuh untuk proses adaptasi.

4. Setelah 1 bulan (waktu adaptasi), tanaman dipangkas $15 \mathrm{~cm}$ dari pangkal tanaman atau lebih kurang 2 ruas dari tanah untuk menyeragamkan.

5. Kemudian setiap minggu dilakukan pengamatan.

6. Setelah 45 hari dilakukan pemanenan untuk mengukur jumlah produksi.

Tahapan pemeliharaan tanaman meliputi:

1. Tanaman dibersihkan dari gulma dan parasit setiap 3 hari.

2. Daun yang layu dipotong dan dibuang.

3. Tidak ada proses penyiraman dan pemupukan pada tahap ini.

Evaluasi Kandungan Nutrien Mutan Rumput Gajah Kultivar Taiwan

Tanaman yang telah di evaluasi produksi kemudian diseleksi dengan cara skoring untuk menentukan 10 tanaman terbaik. Penentuan nilai skoring mutan rumput gajah kultivar Taiwan dapat dilihat pada Tabel 1.

Tanaman yang telah diseleksi kemudian dipotong dan dilakukan penimbangan bobot segar.Tanaman dipotongpotong ukuran 3-4 cm, kemudian tanaman dioven pada suhu $60^{\circ} \mathrm{C}$ selama 1 minggu. Tanaman ditimbang bobot keringnya dan dihaluskan dengan cara diblender.

\section{Peubah}

\section{Aklimatisasi}

Pengukuran dilakukan setiap minggu selama 4 minggu. Pengukuran dimulai saat penutup sementara tanaman dibuka. Peubah yang diukur:

1. Tingkat kematian $\Sigma$ Tanaman yang mati tiap perlakuan Total Tanaman $\times 100 \%$

2. Tinggi Tanaman, diukur dengan cara mengukur daun yang terpanjang dari pangkal tanaman.

3. Jumlah Daun, dilakukan perhitungan secara visual dengan melihat pertambahan daun setiap minggu

Evaluasi Produksi Mutan Rumput Gajah Kultivar Taiwan Skala Lapang

Pengambilan data dilakukan setiap 7 hari selama 42 hari. Peubah yang diamati berupa:
Tabel 1 Kriteria penilaian skoring mutan rumput gajah kultivar Taiwan.

\begin{tabular}{ccc}
\hline No & \multicolumn{1}{c}{ Kriteria } & Nilai Skor \\
\hline 1 & Variabel $\geq$ rata-rata+standard deviasi & 1,0 \\
2 & Variabel $\geq$ rata-rata & 0,5 \\
3 & Variabel < rata-rata & 0 \\
\hline
\end{tabular}

Hasil sampel dianalisis proksimat di Pusat Penelitian Sumberdaya Hayati dan Bioteknologi Lembaga Penelitian dan Pemberdayaan Masyarakat IPB.

1. Tinggi batang diukur dengan cara memilih batang yang tertinggi dan mengukur tinggi batang dari pangkal tanaman ke ruas batang tertinggi. Batang yang diukur ditandai untuk pengukuran selanjutnya.

2. Jumlah anakan dihitung dengan cara menghitung jumlah tunas yang muncul dari dalam tanah setiap minggu.

3. Diamater batang diukur dengan cara mengukur diameter bagian diameter batang terbesar pada tanaman dan ditandai letak bagian yang diukur untuk pengukuran selanjutnya.

4. Lebar daun diukur dengan cara memilih daun yang terlebar kemudian diukur bagian yang terlebar dan ditandai letak bagian yang diukur untuk pengukuran selanjutnya.

5. Setelah tanaman mencapai umur 45 hari tanaman dipanen untuk ditimbang jumlah produksinya.

Kandungan Nutrien Mutan Rumput Gajah Kultivar Taiwan

Kandungan nutrisi masing-masing mutan rumput gajah kultivar Taiwan yang terpilih berdasarkan skoring dilakukan analisis proksimat untuk memperoleh kadar air, abu, lemak, protein, serat kasar (AOAC 2005)

\section{Rancangan Percobaan dan Analisis Data}

Rancangan yang digunakan dalam penelitian aklimatisasi adalah Rancangan Acak Lengkap (RAL) Faktorial dengan faktor A adalah jenis mutan T2, T4, K4 dan faktor B adalah jenis media tanam pasir (P), tanah (T), kombinasi pasir dan tanah (PT). Masing-masing perlakuan diulang sebanyak 30 kali.

Penelitian tahap evaluasi produksi skala lapang didesain dengan menggunakan Rancangan Acak Lengkap dengan perlakuan perbedaan jenis mutan dengan ulangan sebanyak 21 (T2), 25 (T4) dan 22 (K4). Penelitian tahap kandungan nutrien tanpa menggunakan rancangan percobaan.

Data akan dianalisis menggunakan analisis ragam (ANOVA) dengan menggunakan instrumen SPSS, selanjutnya jika terdapat perbedaan yang nyata maka dilanjutkan dengan uji lanjut Duncan (Mattjik \& Sumertajaya 2006). 


\section{HASIL DAN PEMBAHASAN}

\section{Aklimatisasi Mutan Rumput Gajah Kultivar Taiwan Skala Rumah Kaca}

\section{Tingkat Kematian Tanaman}

Tingkat kematian tanaman dalam proses aklimatisasi menggambarkan ketidakmanpuan tanaman untuk beradaptasi pada lingkungan baru dari perlakuan yang diberikan. Hasil penelitian diperoleh tanaman hidup sejumlah 68 tanaman, yakni T2 sebanyak 21 mutan, T4 sebanyak 25 mutan dan K4 sebanyak 22 mutan, sehingga nilai total tanaman perlakuan yang mati adalah 22 tanaman, yakni : T2 sebanyak 9 mutan, T4 sebanyak 5 mutan dan K4 sebanyak 8 mutan (Tabel 2).

Hasil sidik ragam pengaruh perlakuan media dan jenis mutan menunjukkan bahwa jenis media berbeda nyata $(\mathrm{P}<0,05)$ terhadap tingkat kematian tanaman. Perlakuan kombinasi pasir dan tanah (1:1) nyata menurunkan tingkat kematian tanaman dibandingkan dengan media tunggal media pasir dan media tanah. Hasil menunjukkan media kombinasi pasir dan tanah mampu memperbaiki tekstur, ketersediaan air dan unsur hara bagi mutan rumput gajah kultivar Taiwan, sehingga perkembangan akar menjadi bagian penting dalam menentukan keberlangsungan hidup tanaman. Semakin rendah angka kematian maka semakin baik media yang digunakan. Tingginya tingkat kematian dalam proses aklimatisasi disebabkan oleh beberapa faktor yaitu media tanam, umur tanaman, kontaminasi dan kemampuan adaptasi tanaman, hal ini sesuai dengan pernyataan Elmi (2001) yang menyatakan faktor yang menentukan keberhasilan tahap aklimatisasi adalah media tanam, peralatan dan cara pengeluaran serta penanaman bibit.

Tingginya tingkat keberhasilan aklimatisasi pada tanaman selama penelitian dipengaruhi oleh proses adaptasi yang diberikan kepada tanaman selama lebih kurang 2 minggu berupa menutup tanaman dengan menggunakan wadah transparan bekas kemasan gelas air mineral dan memotong daun yang panjang untuk mengurangi proses laju transpirasi. Hal ini sesuai dengan pernyataan Zulkarnain (2009) yang menyatakan defisit air dapat mempengaruhi laju fotosintesis, pada keadaan laju transpirasi yang tinggi, daun akan mengalami layu sementara, dan menutup stomata.

Dalam keadaan tersebut penyerapan C02 ke dalam daun akan menurun dan laju fotosintesis juga menurun.

Tabel 2 Pengaruh media dan jenis mutan terhadap tingkat kematian tanaman (\%)

\begin{tabular}{lcccc}
\hline \multirow{2}{*}{ Media } & \multicolumn{3}{c}{ Jenis Mutan } & \multirow{2}{*}{ Rataan } \\
\cline { 2 - 4 } & T2 & T4 & K4 & \\
\hline P & 30 & 20 & 30 & $30^{\mathrm{b}}$ \\
T & 30 & 10 & 40 & $27^{\mathrm{b}}$ \\
PT & 30 & 20 & 10 & $22^{\mathrm{a}}$ \\
\hline \multicolumn{1}{r}{ Rataan } & $30^{\mathrm{b}}$ & $19^{\mathrm{a}}$ & $30^{\mathrm{b}}$ & 24 \\
\hline
\end{tabular}

Superskrip yang berbeda pada baris dan kolom yang sama menunjukkan rataan berbeda nyata $(\mathrm{P}<0,05)$
Tabel 3 Pengaruh media dan jenis mutan terhadap rataan tinggi tanaman $(\mathrm{cm})$

\begin{tabular}{lcccc}
\hline \multirow{2}{*}{ Media } & \multicolumn{3}{c}{ Jenis Mutan } & \multirow{2}{*}{ Rataan } \\
\cline { 2 - 4 } & T2 & T4 & K4 & \\
\hline P & $24,57 \pm 11,18$ & $34,75 \pm 9,47$ & $32,57 \pm 10,91$ & $30,82 \pm 10,93$ \\
T & $29,71 \pm 13,54$ & $39,33 \pm 9,76$ & $24,83 \pm 12,11$ & $32,32 \pm 12,76$ \\
PT & $35,57 \pm 9,18$ & $45,37 \pm 11,03$ & $25,78 \pm 6,98$ & $35,17 \pm 12,11$ \\
\hline
\end{tabular}

Rataan $29,95 \pm 11,79^{\mathrm{b}} 39,80 \pm 10,59^{\text {a }} 27,68 \pm 9,96^{\mathrm{b}}$

Superskrip yang berbeda pada baris yang sama menunjukkan rataan berbeda nyata $(\mathrm{P}<0,05)$

Keadaan seperti ini yang sering menyebabkan tanaman dalam proses aklimatisasi memiliki keberhasilan yang rendah karena persentase hidup yang rendah.

\section{Tinggi Tanaman}

Hasil pengamatan tinggi tanaman mutan rumput gajah dirumah kaca dapat dilihat dari rata-rata pertumbuhan tanaman dari Tabel 3. Hasil analisis ragam menunjukkan interaksi antara mutan rumput gajah dan jenis media tidak menunjukkan perbedaan nyata, akan tetapi pada tinggi tanaman perlakuan tunggal jenis mutan menunjukkan perbedaan yang nyata $(\mathrm{P}<0,05)$.

Nilai tertinggi dari rata-rata tinggi tanaman didapat pada jenis mutan T4 yang menggunakan media kombinasi Pasir+Tanah yaitu $45,37 \mathrm{~cm}$ dan nilai yang terendah terdapat pada jenis mutan T2 yang menggunakan media Pasir yaitu 24,57 cm. Hal ini sesuai dengan pernyataan Sandra (2001) yang menyatakan bahwa pada usia semai harus menggunakan media yang mempunyai kemampuan mengikat air yang cukup baik. Media yang remah akan memudahkan pertumbuhan akar dan melancarkan aliran air, mudah mengikat air dan hara, tidak mengandung toksin atau racun, kandungan unsur haranya tinggi, tahan lapuk dalam waktu yang cukup lama (Waluyo, 2009). Sumarsono (2005) menyatakan bahwa media merupakan salah satu faktor lingkungan yang berfungsi menyediakan unsur hara dan air bagi pertumbuhan tanaman. Campuran dua macam media dapat memperbaiki kekurangan masing-masing media tersebut, antara lain kemampuan mempertahankan kelembaban media.

\section{Jumlah Daun}

Hasil pengamatan jumlah daun menunjukkan interaksi antara mutan rumput gajah dan jenis media tidak menunjukkan perbedaan nyata, akan tetapi pada jumlah daun perlakuan tunggal jenis mutan menunjukkan perbedaan yang nyata $(\mathrm{P}<0,05)$ (Tabel 4$)$.

Tabel 4 Pengaruh media dan jenis mutan terhadap rataan jumlah daun (helai)

\begin{tabular}{lcccc}
\hline \multirow{2}{*}{ Media } & \multicolumn{3}{c}{ Jenis Mutan } & \multirow{2}{*}{ Rataan } \\
\cline { 2 - 4 } & $\mathrm{T} 2$ & $\mathrm{~T} 4$ & $\mathrm{~K} 4$ & \\
\hline $\mathrm{P}$ & $3,43 \pm 1,40$ & $6,13 \pm 1,55$ & $5,00 \pm 1,63$ & $4,91 \pm 1,85$ \\
$\mathrm{~T}$ & $5,29 \pm 1,70$ & $5,44 \pm 1,03$ & $4,00 \pm 2,28$ & $5,00 \pm 1,69$ \\
$\mathrm{PT}$ & $5,86 \pm 2,34$ & $6,75 \pm 1,49$ & $3,89 \pm 1,76$ & $5,42 \pm 2,19$ \\
\hline Rataan & $4,86 \pm 1,88^{\mathrm{b}}$ & $6,08 \pm 1,41^{\mathrm{a}}$ & $4,27 \pm 1,86^{\mathrm{b}}$ & \\
\hline
\end{tabular}

Superskrip yang berbeda pada baris yang sama menunjukkan rataan berbeda nyata $(\mathrm{P}<0,05)$ 
Jumlah daun tertinggi terdapat padajenis mutan T4 yang menggunakan media kombinasi Pasir+Tanah yaitu 6,75 helai dan jumlah daun terendah terdapat pada jenis mutan T2 yang menggunakan media Pasir yaitu 3,43 helai. Jenis mutan memberikan pengaruh yang nyata terhadap pertumbuhan aklimatisasi. Hal ini sesuai dengan pernyataan Prawirawinata (1988) yang menyatakan bahwa hormon didalam tanaman merupakan produk metabolit, sehingga kandungan hormon endogen didalam tanaman akan berbeda jika umur dan jenis tanaman berbeda. Semakin tua umur tanaman akumulasi jumlah metabolit sekunder dalam hal ini hormon endogen akan semakin banyak tersimpan didalam sel tanaman.

Diketahui bahwa hormon di dalam tanaman merupakan produk metabolit, sehingga kandungan hormon endogen di dalam tanaman akan berbeda jika umur tanaman berbeda (Kaufman et al. 1999). Semakin tua umur tanaman akumulasi jumlah metabolit sekunder dalam hal ini hormon endogen akan semakin banyak tersimpan di dalam sel tanaman.

Pengaruh faktor luar merupakan faktor utama serta pendukung dalam menentukan keberhasilan aklimatisasi diantaranya adalah intensitas cahaya, suhu, air dan kelembaban. Hal ini sejalan dengan pendapat Muhakka et al. (2013) yang menyatakan bahwa apabila cahaya yang diberikan pada tanaman dalam jumlah yang optimum maka akan menyebabkan terbukanya stomata dan terjadinya proses fotosintesis yang sehingga unsur hara bagi tanaman terpenuhi. Diketahui bahwa intensitas cahaya yang diperlukan untuk aklimatisasi

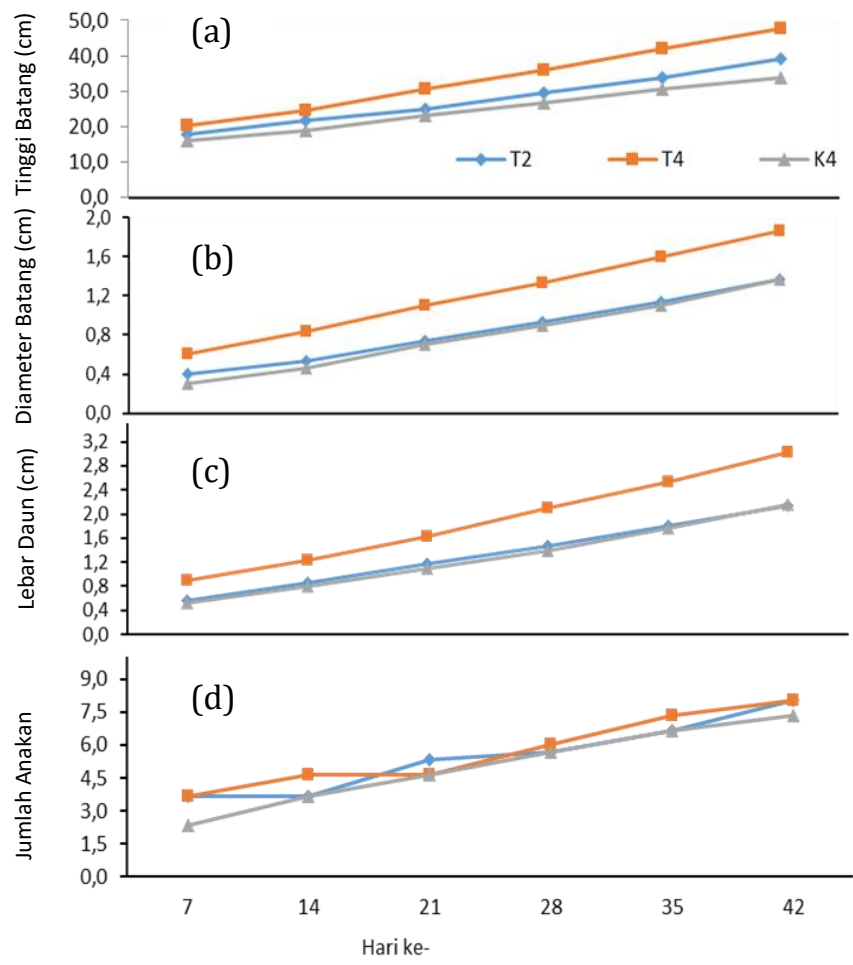

Gambar 1 Pengaruh jenis mutan terhadap (a) tinggi tanaman, (b) diameter batang, (c) lebar daun, (d) jumlah anakan berkisar antara 40-50\%, sehingga dibutuhkan pelindung seperti paranet untuk menaungi dan melindungi tanaman yang diaklimatisasi dari sinar matahari langsung. Sebagaimana dalam penelitian ini digunakan wadah transparan bekas kemasan gelas air mineral untuk melindungi dari sinar matahari langsung.

\section{Evaluasi Produksi Mutan Rumput Gajah Taiwan Skala Lapang}

Hasil pengamatan pertumbuhan tananaman dilahan lapang dapat dilihat dari grafik pertumbuhan pada Gambar 1. Berdasarkan Gambar 1b, tanaman yang memiliki diameter terbesar berasal dari tanaman mutan T4 dengan diameter rata-rata $1,87 \mathrm{~cm}$ disusul dengan tanaman mutan T2 dan mutan K4 dengan dengan diameter rata-rata $1,37 \mathrm{~cm}$. Berdasarkan Gambar 1c, tanaman yang memiliki daun terlebar berasal dari tanaman mutan T4 dengan lebar rata-rata $3,03 \mathrm{~cm}$ disusul dengan tanaman yang mutan K4 dengan lebar rata-rata $2,17 \mathrm{~cm}$ dan yang terendah adalah tanaman mutan T2 dengan lebar rata-rata $2,13 \mathrm{~cm}$. Berdasarkan Gambar 1d, tanaman yang memiliki jumlah anakan terbanyak berasal dari tanaman mutan $\mathrm{T} 4$ dan mutan $\mathrm{T} 2$ dengan jumlah rata-rata $8 \mathrm{~cm}$ dan yang terendah adalah tanaman mutan $\mathrm{K} 4$ dengan jumlah rata-rata $7 \mathrm{~cm}$.

Dari seluruh grafik pada Gambar 1 dapat dilihat bahwa nilai tinggi tanaman sejalan dengan nilai diameter, lebar daun dan jumlah anakan. Perbedaan hasil disetiap peubah terjadi karena ada perbedaan perlakuan dan pengaruh perubahan genetik yang terjadi dalam proses kultur jaringan hal ini sesuai dengan pernyataan Datta (2007) yang menyatakan keragaman dapat ditingkatkan melalui kombinasi teknik in vitro melalui kultur jaringan dengan perlakuan mutasi fisik radiasi sinar gamma. Aplikasi radiasi untuk mendapatkan keragaman genetik baru rumput gajah dapat dilakukan terhadap populasi kalus embriogenik hasil kultur in vitro.

Berdasarkan hasil penelitian Astuti (2007) perlakuan dosis iradiasi dapat menimbulkan kelainan morfologi seperti diameter batang kecil, daun kecil, dan daun kuning kehijauan. Hal ini juga didukung oleh hasil penelitian Hapsari (2004) yang menyatakan bahwa teknik mutasi iradiasi sinar gamma berpengaruh terhadap jumlah daun sehingga mempengaruhi morfologi tanaman tersebut. Karena selama penelitian terjadi musim kemarau panjang seharusnya dilakukan pemanenan mutan rumput gajah Taiwan pada umur 60 hari tetapi karena banyak tanaman yang sudah mulai berbunga (fase generatif) di umur 44 hari maka dilakukan pemanenan di umur 45 hari untuk menjaga kualitas kandungan nutrisi mutan rumput gajah Taiwan tersebut. Hal ini sesuai dengan pernyataan VillanuevaAvalos (2008) yang menyatakan kualitas nutrien tanaman lebih tinggi pada fase vegetatif dan akan berkurang saat masuk fase generatif. Cepatnya fase generatif rumput gajah ini diduga karena pengaruh induksi sinar gamma yang menyebabkan perubahan genetik. 
Tabel 5 Pengaruh jenis mutan terhadap rataan bobot panen tanaman (g rumpun ${ }^{-1}$ )

\begin{tabular}{llll}
\hline Media & \multicolumn{3}{c}{ Jenis Mutan } \\
\cline { 2 - 4 } Tanam & \multicolumn{1}{c}{ T2 } & \multicolumn{1}{c}{ T4 } & \multicolumn{1}{c}{ K4 } \\
\hline $\mathrm{P}$ & $1044 \pm 98,75$ & $1276 \pm 147,33$ & $903 \pm 201,65$ \\
$\mathrm{~T}$ & $1164 \pm 145,91$ & $1287 \pm 83,12$ & $978 \pm 222,52$ \\
$\mathrm{PT}$ & $1386 \pm 123,23$ & $1504 \pm 185,67$ & $1125 \pm 7,35$ \\
\hline & $1198 \pm 186,99 \mathrm{~b}$ & $1353 \pm 172,95^{\mathrm{a}}$ & $1002 \pm 182,47^{\mathrm{c}}$ \\
\hline
\end{tabular}

Superskrip yang berbeda pada baris yang sama menunjukkan rataan berbeda nyata $(\mathrm{P}<0,05)$. T2,T4 dan K4 merupakan jenis mutan

Berdasarkan Tabel 5, bobot rata-rata produksi rumput gajah yang dipanen umur 45 hari selama musim kemarau yaitu T2 1198 g rumpun $^{-1}$, T4 1353 g rumpun $^{-1}$ dan K4 1002 g rumpun $^{-1}$. Hasil produksi rumput gajah Taiwan lebih rendah jika dibandingkan dengan penelitian Manalu (2012) yang menggunakan perlakuan dolomit 12,5 ton ha-1 yang memperoleh hasil $2150 \mathrm{~g} \mathrm{rumpun}^{-1}$. Rendahnya nilai produksi rumput gajah disebabkan oleh tidak adanya pemberian pupuk terhadap tanaman yang ditanam di lahan lapang dan juga disebabkan oleh musim kemarau yang berkepanjangan. Jika dikonversi ke produksi tanaman periode panen maka rata-rata produksi rumput gajah Taiwan T2 sebesar $1198 \mathrm{~kg} \mathrm{ha}^{-1}$, T4 $1353 \mathrm{~kg} \mathrm{ha}^{-1}$ dan K4 $1002 \mathrm{~kg} \mathrm{ha}^{-1}$. Hal ini sesuai dengan pernyataan Affandi (2004) yang menyatakan perbandingan hasil produksi rumput gajah antara yang dipupuk dan yang tidak dipupuk berkisar $3: 1$.

\section{Kandungan Nutrien Mutan Rumput Gajah Taiwan}

Berdasarkan nilai skoring ditentukan 10 tanaman yaitu dapat dilihat pada Tabel 6. Dari hasil penilaian skoring pada Tabel 6 tanaman yang memiliki nilai $\geq 3,0$ merupakan tanaman yang terbaik. Tanaman yang memiliki nilai skor $\geq 3,0$ berjumlah 10 tanaman. Tanaman hasil seleksi skoring kemudian dianalisis proksimat. Hasil analisis proksimat tanaman yang terpilih terdapat pada Tabel 7.

Berdasarkan Tabel 7, mutan yang memiliki kandungan nutrien terbaik adalah mutan T2PT7 dengan protein kasar $11,17 \%$ dan serat kasar $24,67 \%$. Kandungan nutrien mutan T2PT7 lebih rendah jika

Tabel 6 Nilai skoring data hasil pengamatan mutan

\begin{tabular}{ccccc}
\hline \multirow{2}{*}{ Nilai } & \multicolumn{3}{c}{ Jenis Mutan } & Total \\
\cline { 2 - 4 } & T2 & T4 & K4 & \\
\hline 0,0 & 4 & 5 & 3 & 12 \\
0,5 & 5 & 4 & 6 & 15 \\
1,0 & 4 & 6 & 7 & 17 \\
1,5 & 1 & 4 & 2 & 7 \\
2,0 & 2 & 0 & 0 & 2 \\
2,5 & 2 & 2 & 1 & 5 \\
3,0 & 0 & 2 & 1 & 3 \\
3,5 & 2 & 1 & 1 & 4 \\
4,0 & 1 & 1 & 1 & 3 \\
\hline Total & 21 & 25 & 22 & 68 \\
\hline
\end{tabular}

T2, T4 dan K4 merupakan jenis mutan
Tabel 7 Kandungan nutrien (analisis proksimat) dari beberapa jenis mutan (\%)

\begin{tabular}{lccccc}
\hline $\begin{array}{l}\text { Jenis } \\
\text { Mutan }\end{array}$ & Air & Abu & $\begin{array}{c}\text { Lemak } \\
\text { kasar }\end{array}$ & $\begin{array}{l}\text { Protein } \\
\text { kasar }\end{array}$ & $\begin{array}{l}\text { Serat } \\
\text { Kasar }\end{array}$ \\
\hline T2P5 & 8,17 & 20,78 & 2,37 & 8,20 & 25,11 \\
T2T1 & 7,86 & 14,61 & 2,34 & 9,61 & 24,64 \\
T2PT7 & 7,78 & 12,66 & 2,31 & 11,17 & 24,67 \\
T4T4 & 9,67 & 14,09 & 2,57 & 9,37 & 24,32 \\
T4PT2 & 7,80 & 13,10 & 2,09 & 7,98 & 25,48 \\
T4PT6 & 8,39 & 11,59 & 2,37 & 8,97 & 26,39 \\
T4PT8 & 7,95 & 10,82 & 2,14 & 9,11 & 26,55 \\
K4P1 & 7,25 & 10,70 & 2,24 & 9,53 & 26,33 \\
K4T1 & 7,79 & 9,96 & 1,68 & 7,39 & 26,63 \\
K4T8 & 10,23 & 8,87 & 1,93 & 5,99 & 28,11 \\
T2P5 & 8,17 & 20,78 & 2,37 & 8,20 & 25,11 \\
\hline
\end{tabular}

Nilai Analisis Proksimat dikeluarkan oleh Lembaga Penelitian dan Pemberdayaan Masyarakat IPB No. 237/I.T.3/PM/2017

dibandingkan dengan penelitian Manalu (2012) yang menggunakan perlakuan dolomit 12,5 ton ha-1 memperoleh hasil protein kasar 11,97\%. Rendahnya nilai kandungan nutrisi disebabkan beberapa faktor salah satunya adalah umur pemanenan yang semakin tua sangat berpengaruh terhadap kandungan protein kasar. Hasil penelitian Budiman (2012) menunjukkan terjadinya penurunan protein kasar yang sangat drastis dari $12,94 \%$ pada panen umur delapan minggu menjadi 8,77\% pada umur panen 12 minggu. Selain umur panen, pemupukan juga erat kaitannya dengan kandungan protein kasar, terutama karena rumput gajah responsif terhadap pupuk nitrogen. Shokri (2005) melaporkan kandungan protein kasar hasil penelitiannya sebesar 12$13 \%$ pada pemberian pupuk sebanyak $200 \mathrm{~kg} \mathrm{ha}^{-1}$ tahun $^{-}$ 1 menggunakan urea maupun dengan campuran feses domba. Faktor lain yang menentukan nilai kandungan nutrisi tanaman adalah efek induksi mutasi mutan rumput gajah Taiwan yang membuat variasi genetik hal ini sesuai dengan pernyataan Parekh (2000) yang menyatakan bahwa iradiasi sinar gamma dengan dosis tertentu menyebabkan mutasi secara acak.

\section{SIMPULAN}

Media yang terbaik untuk proses aklimatisasi mutan rumput gajah Taiwan hasil induksi in vitro adalah media kombinasi antar pasir dan tanah (1:1). Mutan yang memiliki nilai produksi yang terbaik adalah mutan T4. Jenis mutan yang memiliki kandungan nutrien terbaik adalah mutan T2PT7.

\section{DAFTAR PUSTAKA}

Affandi. 2004. Pengaruh pemupukan beberapa paket N, P dan K terhadap pertumbuhan dan produksi segar Rumput Gajah (Pennisetum purpureum) cv Taiwan pemotongan pertama pada Tanah Podzolik Merah Kuning (PMK). Padang (ID). Universitas Andalas Padang.

Astuti NP. 2007. Kandungan Reserpin Kultur Kalus Pule Pandak (Rauvolfia verticillata (Lour.) Baillon) Setelah Dielisitasi Dengan Cendawan Pytium sp [skripsi]. Surakarta (ID): Universitas Sebelas Maret. 
Budiman. 2012. Study of morphological development at vegetative and reproductive phases of three elephant grass (Pennisetum purpureum Schum) cultivars [disertasi]. Yogyakarta (ID): Universitas Gadjah Mada.

Chemisquy MA, Giussani LM, Scataglini MA, Kellogg EA \& Morrone 0. 2010. Phylogenetic studies favour the unification of Pennisetum, Cenchrus and Odontelytrum (Poaceae): A combined nuclear, plastid and morphological analysis, and nomenclatural combinations in Cenchrus. Annals of Botany. 106 (1):107-130.

Datta MM, Mukherjee P, Ghosh B, \& Jha TB. 2007. In vitro clonal propagation of biodiesel plant (Jatropha curcas L.) Current Science. 93 (10): 1438-1442.

Elly FH, Sinaga BM, Kuntjoro SU \& Kusnadi N. 2008. Pengembangan Usaha Ternak Sapi Rakyat Melalui Integrasi Sapi-Tanaman di Sulawesi Utara. Jakarta (ID): Badan Penelitian dan Pengembangan Pertanian.

Elmi S. 2001. Masa Kritis dalam Penanaman Bibit Anggrek dalam Botol. Surabaya (ID): East Java Orchid.

Heuze V, Tran G, Giger-Reverdin S, \& Lebas F. 2016. Elephant grass (Pennisetum purpureum). Feedipedia, a programme by INRA, CIRAD, AFZ and FAO https://www.feedipedia.org/node/395

Hapsari L. 2004. Induksi mutase pada melati (Jasminum spp) melalui iradiasi sinar gamma [skripsi]. Bogor (ID): Institut Pertanian Bogor

Husni A M. \& Kosmiatin 2018. Rumput Gajah dan Peluang Perbanyakan Bibit Melalui Kultur Jaringan untuk memenuhi Kebutuhan Pakan Hijauan Ternak Bermutu. Jakarta (ID): IAARD Press.

Husni A, Hustami S, Kosmiatin M \& Mariska I. 2004. Seleksi in vitro tanaman kedelai untuk meningkatkan sifat ketahanan terhadap cengkaman kekeringan. Laporan Tahunan Penelitian TA 2003. Bogor (ID): Balai Besar Penelitian dan Pengembangan Bioteknologi dan Sumberdaya Genetik Pertanian.

Manalu, S. 2012. Pengaruh pemberian dolomit terhadap produktivitas dan kualitas rumput raja dan rumput Taiwan pada tanah latosol Ciampea Bogor [skripsi]. Bogor (ID): Institut Pertanian Bogor.

Manurung T, Sajimin, Prawiradiputra BR, Nurhayati, Sutedi E, Yuhaeni S \& Sumarto. 2001. Uji palatabilitas dan kecernaan plasma nutfah tanaman pakan ternak untuk seleksi lebih lanjut. Laporan Tahunan T.A. 2001. Bogor (ID): Balitnak Ciawi.

Muhakka, Napoleon A, \& Isti'adah H. 2013. Pengaruh pemberian asap cair terhadap pertumbuhan rumput raja (Pennisetum purpureophoides). Pastura. 3(1): 30 - 34.

Nurhayu A, Saenap A \& Sariubang. 2009. Induksi beberapa jenis rumput dan leguminosa unggul sebagai penyedia hijauan pakan pada lahan kering dataran rendah di kabupaten Pinrang. Seminar Nasional Teknologi Peternakan dan Veteriner Makasar. Makasar (ID): Badan Penelitian dan Pengembangan Pertanian.

Parekh S, Vinci VA \& Strobel RJ. 2000. Improvement of microbial strain and fermentation processes. Applied Microbialogy Biotechnology. 54 (3): 287-301.

Prawirawinata W \& Haran S. 1988. Dasar-Dasar Fisiologi Tumbuhan. Bogor (ID): Institut Pertanian Bogor.

Sajimin, Kompiang IP, Supriyati \& Suratmini NP 2001. Penggunaan biofertilizer untuk peningkatan produktifitas hijauan pakan rumput gajah (Pennisetum purpureum cv Afrika) pada lahan marjinal di Subang Jawa Barat. Media Peternakan. 24 (2): 46 - 50.

Sandra E. 2001. Membuat Anggrek Rajin Berbunga. Cetakan I. Jakarta (ID): Agromedia Pustaka.
Shokri J. 2005. Effect of sheep manure application on the production of dwarf napier grass (Pennisetum purpureum cv. Mott) [tesis]. Kuala Lumpur (MYS): Universiti Putra Malaysia.

Sumarsono. 2005. Peranan Pupuk Organik untuk Perbaikan Penampilan dan Produksi Hijauan Rumput Gajah Pada Tanah Cekaman Salinitas dan Kemasaman. Semarang (ID): Universitas Diponegoro.

Villanueva-Avalos JF. 2008. Effect of defoliation patterns and developmental morphology of forage productivity and carbohydrate reserves in WW- B.Dahl grass (Bothriochloa bladhii Retz) ST Blake. [disertasi]. Lubbock (ID): Texas Tech. University.

Waluyo, L. 2009. Mikrobiologi Lingkungan. Malang (ID): UMM Press.

Wattimena GA. 1992. Bioteknologi Tanaman I. Bogor (ID): Pusat Antar Universitas Bioteknologi Institut Pertanian Bogor.

Zulkarnain. 2009. Kultur Jaringan Tanaman; Solusi Perbanyakan Tanaman Budi Daya. Jakarta (ID): Bumi Aksara. 